\title{
A STUDY ON THREE MAJOR FOREST INVASIVE SPECIES COMMON ALONG THE SHIVALIK BELT OF HIMACHAL PRADESH KASHMIR, PUNJAB AND UTTARAKHAND, INDIA
}

\author{
Priya Padmanabhan ${ }^{1}$, Nidhi Srivastava ${ }^{2}$, Gurpreet Kaur ${ }^{3}$ and Ajay Thakur ${ }^{1}$ \\ ${ }^{1}$ Genetics and Tree Propagation Division, Forest Research Institute, Dehradun, Uttarakhand \\ ${ }^{2}$ Indira Gandhi National Forest Academy, Dehradun, Uttarakhand \\ ${ }^{3}$ Chitkara Business School, Chitkara University, Punjab
}

\section{Review Paper}

\begin{abstract}
Non-native/distant species that occur outside of their natural existence with good scattering ability are known as forest invasive species (FIS). Some alien species become invasive when they are introduced either purposely or accidentally, to a new environment where they exhibit an ability to conquer and dominatethe native species. There are ample literatures on such species in IHR (Indian Himalayan Region), when compared less is known in the Shivaliks. The present study is an attempt to review on three major FIS of the Shivalik belt of Himachal Pradesh, Kashmir, Punjab and Uttarakhand of North West India. Some of the plants that were intended to be beneficial have developed a notorious habit, as they are known for their adaptability, persistence, reproductive ability and exclusion of competition. It has drastically changed the composition of natural habitats, as well as the variety and dynamics of native flora. These species have become established outside of their native ranges and have learnt to thrive in this new ecological area. But with time, the situation has worsened as a result of a lack of knowledge, inadequate information about the species, its range and a large ecological amplitude.
\end{abstract}

Keywords: Alien, Habitat, Himalaya, Invasive, Shivaliks.

\section{INTRODUCTION}

Invasions on a biological front are a common and notable part of global environmental change, causing damage to the native inbuilt ecosystem by altering the population, framework, quality and functions (Vitousek et al., 1996; Tilman, 1999; Ehrenfeld, 2003; Yurkonis et al., 2005). Alien species invasion is as a global issue and one of the major reasons for this changeworldwide (Millennium Ecosystem Assessment, 2005). Mountain ecosystems, particularly high mountains are assumed to be more immune to invasions among the terrestrial ecosystems (Pauchard et al., 2009).

This is due to numerous biological filters that alien plants face as they migrate up higher in the mountains (Alexander et al. 2011; McDougall et al. 2011). But however, if an alien species attempts to establish itself in the mountains, due to the rugged mountain terrains, it easily proliferates and becomes difficult to contain and maintain (McDougall et al., 2011). Climatic conditions are the most significant determinants of global vegetation trends, and it has a major impact on forest ecology (Kirschbaum, 2000). The proliferative spread combined with climate change is causing irreversible and irreparable loss (Myers 1993; Hulme 2003, 2009).

Forest invasive species (FIS) is described by the International Union for Conservation of Nature and Natural Resources (IUCN) as an alien species that becomes established in a natural habitat, creates change and poses a

*Corresponding author: anushapriya19@gmail.com 
threat to the native biological diversity (Sekar, 2012).Population extinctions, changes in hydrology, and ecosystem functions are all caused by FIS (McGeoch et al., 2010).

The Himalaya has been named one of the world's 36 biodiversity hotspots because of its rare and diverse biodiversity, which is under threat (Palni and Rawal, 2013; Sharma et al., 2016). A significant portion of this hotspot is contributed by the Indian Himalayan Region (IHR). This area provides a wide range of products and ecosystem services that allows most of the population to live within the physical boundaries of these forests. IHR has a renowned diversified forest ecosystem (Singh, 2014). This diversified system thereby enhances the agro-ecosystem of the area by transforming the available biomass to cooking energy and other forms of energy (Negi et al., 2018).

A massive sum of 190 FIS has been recorded in the IHR according to previous literature (Sekar, 2012).A search on the science web yielded a plethora of studies from IHR that are linked to invasive alien plant species(Pathak et al., 2019). This emphasises the importance of plant invasion research in the Shivalik area better known as the outerHimalayas, where only limited studies are available. As a result, the current study was planned to assess the state of research on the FIS in the Shivaliks.
Lantana camara, Parthenium hyterophorus and Ageratum conyzoides are the three major FIS along the Shivalik belt of Himachal Pradesh, Kashmir, Punjab and Uttarakhand(Kohli et al., 2004).This study is attempted as a future hope to aid in the development of monitoring measures to combat harmful plant invasions in the Shivalik area.

\section{MATERIALSAND METHODS}

This is an attempt to study three major Forest Invasive Species common along the Shivalik belt of Himachal Pradesh, Kashmir, Uttarakhand and Punjab. Using the available web sources, a detailed review of the available literature (research papers, reviews, inventories, books ande-articles) was taken up. Using keywords such as invasive, alien, non-native, foreign etc.a search was conducted on plant invasions during December 2020 to February 2021. The literatures on IHR or broader perspectives about plant invasions were mostly found. Hence, this study focuses mostly on the literature accessible for IHR, including Google Scholar search results, books, and reports. In addition, a few invasion case studies based on primary data from IHR's western Himalayan region have been considered. It has been attempted to review the available information from the whole of IHR to specifically the Shivaliks.

\section{Study Area}

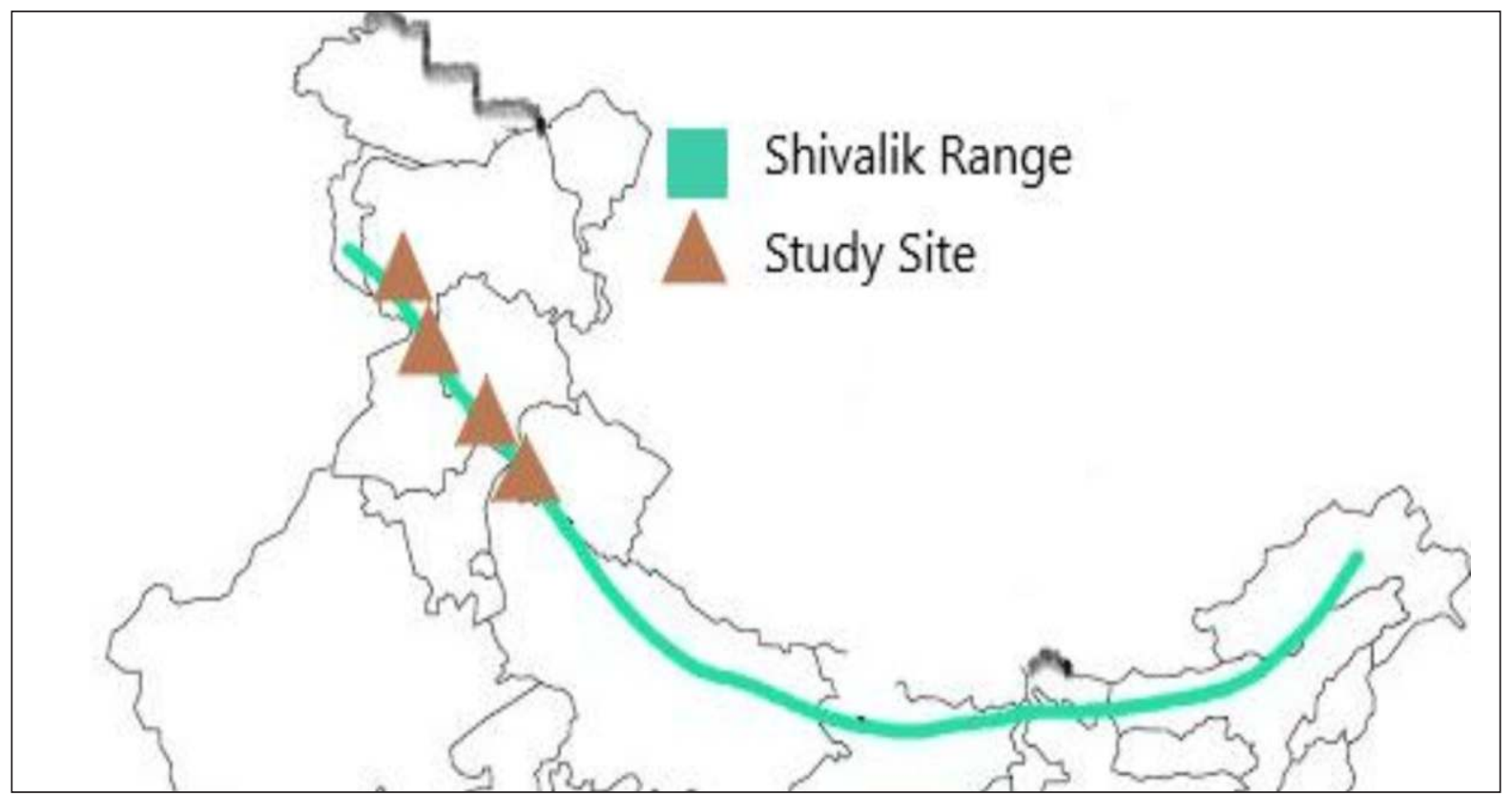

Figure 1: Depicts the extent of the Shivalik range. 


\section{Himachal Pradesh}

Himalayas are well known as a biodiversity hotspot and Himachal Pradesh is a bio-rich Himalayan state. Most foreign species in Himachal Pradesh are from the Asteraceae family, followed by the Poaceae/grass family. Similar findings have been reported from the Indian states of Gujarat (Nagar et al., 2004),Kashmir (Khuroo et al., 2007),Rajasthan (Pandey and Parmar, 1994) andUttar Pradesh (Singh et al., 2010). The same holds true at the national level of India as well (Khuroo et al., 2012).

\section{Kashmir}

The region is mostly made up of a deep elliptical bowlshaped valley bordered by two ranges, south and south-west by the Pir Panjal range of the Lesser Himalaya and the north and north-east by the Zanskar range of the Greater Himalaya. Folding and faulting occurred during the ascent of the Himalaya between the Indian subcontinent and the rest of Asia, forming the Kashmir valley (de Terra, 1934).

\section{Punjab}

Punjab is not blessed with a dense forest cover. However, a great variety of FIS can be found growing in the Shivaliks' small spots (Priya and Chittibabu, 2018).According to published databases and regional reports, the majority of invasive plants, regardless of their origin, belong to the Asteraceae family, with families like Poaceae, Solanaceae, and Fabaceae also dominating (Punjab ENVIS Centre).

\section{Uttarakhand}

The state of Uttarakhand covering 53,483 square kilometres is known for its rough mountainous terrain, with altitudes ranging from 300 to 7,817 metres above sea level. This diversity has resulted in a complex topography and rich floral richness, as well as a diverse ethnic population (Sekar, 2012).

\section{Overall review on FIS}

Kohli et al (2004) identified approximately 60 invasive plants from the Indian region, the majority from South and tropical America and Australia, Africa, Europe, and even Asia, based on accessible databases and regional reports.

The majority of invasive plants, regardless of their origin, are members of the Asteraceae family, while others include the Poaceae, Solanaceae, and Fabacaceae families.
Terrestrial herbaceous weeds (e.g. Ageratum conyzoides and Parthenium hyterophorus) and shrubs (e.g. Lantana camara) are among the most important invasive plants that have caused havoc in a variety of ecosystems (Punjab ENVIS Centre). We tried to study them in detail.

\section{Lantana camara}

Several invasive species have invaded Punjab's forests, with Lantana camara standing out for its quick expansion, intensity of infestation, and stubborn resistance to chopping and burning. Lantana is a tropical American plant that was first introduced to India in 1809 as an attractive hedge in the gardens of Calcutta. Since then, the plant has expanded fast into farm and forest regions, and it is now one of India's most common terrestrial invasive species. Lantana camara has a number of negative effects, including the ability to disrupt the succession cycle by displacing native biota and reducing biodiversity (Murali and Setty, 2001). The structure and floral composition of native communities is altered as a result of its infestations (Sharma and Raghubanshi, 2010). Allelopathic interactions grow as the density of Lantana camara in the forest grows, resulting in a decrease in species richness (Day et al., 2003).Lantana camara has a number of secondary effects due to the presence of dangerous pests such as malarial mosquitoes and tsetse flies, which cause major health problems. These have a big impact on fire regimes because they produce a lot of fuel. The species has been linked to disastrous wildfires in India's diverse regions (Hiremath and Sundaram, 2005).

\section{Parthenium hysterophorus}

After first appearing in Pune, Maharashtra in 1955, the weed has spread throughout India. Parthenium weed was once considered a weed of fallow and wasteland, but it has since evolved into a weed of all crops, as well as forested areas. It's a tropical America-native annual herbaceous plant with a lot of vigour. It has spread throughout a number of tropical and sub-tropical countries. Only in the last several decades, this has become a dominant weed in India. The weed is quite common along road sides, around agricultural fields, and on waste lands in Punjab. Its seeds grow all year (regardless of photoperiod, temperature changes, or seasons) and establish thick monocultural stands if moisture conditions are favourable. It flourishes during the rainy season and in more humid 
Table 1: Highly propagative forest invasive species (FIS) distributed in study areas and respective states.

\begin{tabular}{|l|l|l|l|}
\hline S. No. & State & FIS & References \\
\hline 1 & Himachal Pradesh & $\begin{array}{l}\text { Parthenium hysterophorous } \\
\text { Ageratum conyzoides } \\
\text { Lantana camara Sapiumsebiferu }\end{array}$ & $\begin{array}{l}\text { Kohli et al. (2004) } \\
\text { Singh et al. (2010) } \\
\text { Singh et al. (2014) }\end{array}$ \\
\hline 2 & Kashmir & $\begin{array}{l}\text { Pathenium hysterophorous } \\
\text { Lantana camara } \\
\text { Anthemis cotula } \\
\text { Ageratum conyzoides } \\
\text { Argemone mexicana } \\
\text { Cassia tora }\end{array}$ & $\begin{array}{l}\text { Khuroo et al. (2012) } \\
\text { Khuroo et al. (2007) } \\
\text { Shaheen et al., 2019 }\end{array}$ \\
\hline 3 & Punjab & $\begin{array}{l}\text { Pathenium hysterophorous } \\
\text { Lantana camara } \\
\text { Ageratum conyzoides }\end{array}$ & $\begin{array}{l}\text { Punjab ENVIS Centre } \\
\text { Ageratina adenophora } \\
\text { Lantana camara } \\
\text { Parthenium hysterophorus } \\
\text { Ageratum conyzoides } \\
\text { Rubusneivu }\end{array}$ \\
\hline 4 & Uttarakhand & $\begin{array}{l}\text { Sekar, 2012 } \\
\text { Dobhal et al., (2011) } \\
\text { Rastogi et al., (2015) }\end{array}$ \\
\hline
\end{tabular}

environments and climates. It remains a rosette under water-stressed situations and bolts when rains or moisture arrive. It also regenerates swiftly from root stumps or pieces, including petioles or midribs that have been left in the soil (Kohli and Rani, 1994). Because of its prolific seed production and rapid spread ability, allelopathic influence on other plants, strong competition with crops, and health threat (allergic) to humans and animals, Parthenium hysterophorus is considered a noxious weed. As a result, the eco-system suffers.

\section{Ageratum conyzoides}

This species is native to tropical America, but its range has expanded to include the entire globe. There is no information on the mode and timing of Ageratum's arrival into India. However, according to 'The Flora of British India,' it was recognised to exist in India long before 1882. (Hooker 1882). Furthermore, it was most likely planted as an ornamental plant that later escaped and developed a weedy habit, though no reliable record on this is known (Kohli et al 2006). The weed has expanded widely in both Punjab and Himachal Pradesh's Shivalik, occupying a variety of habitats (forests, plantations, agriculture fields, wastelands, grassland) and currently has a significant impact on the landscape (Kohli et al., 2004).

\section{Mechanisms of Plant Invasion}

Naturalization does not occur in every introduction, only a small percentage of species that are naturalised become invasive (Williamson and Fitter, 1996). Although the number of plants that cross boundaries and become invasive appears to be small, the ones that do have drastic consequences for native species populations, communities, and ecosystem processes.

There are a variety of reasons why invasive plants may flourish and spread quickly in their new surroundings. Disturbance may diminish competition, allowing invaders and invasive species to establish. These plants may be able to evade herbivores or parasites that keep their numbers low in their original habitats. Invasive plants may change their surroundings in order to foster their own community, which can be filled by an introduced plant. There are many theories to plant invasion.

An explanation to invasion patterns across a wide range of systems has not been easier because each invasive species is unique and invasions are unpredictable (Williamson, 1999; Dietz and Edwards, 2006).

\section{Impact of FIS}

Invasion by alien plant species irreversible impact on the native species richness and diversity (Wilcove et 
al., 1998). The edaphic composition, productivity and ecosystem services also gets affected (Huddle et al., 2011). Plant-pollinator interactions are typically hampered by alien plant proliferation, which can alter the existing native populations genetically through hybridization (Vilà et al., 2000; Schweiger et al., 2010).

Parthenium hysterophorous, for example, has contaminated most of the Indian subcontinent, with an estimated 5 million acres afflicted by the species (Kohli et al. 2006). In the early days, newly introduced plant species were found mainly along roadsides, open and shady areas and transition zones in the IHR (Kosaka et al. 2010). However, the rapid construction work through forest areas in recent years have paved way for the alien species to invade forest and mountain ecosystems.

\section{Eradication of FIS}

Only when invasive species are eradicated at an early stage of proliferation are they deemed successful (Khuroo et al., 2012). When a well-established invasive species is eradicated, another previously suppressed non-native species may be released into the area (Caut et al., 2009). As a result, regular surveillance of these places is required to avoid additional invasion. In the Indian Himalaya, the eradication of Lantana camara, a well-established invasive alien plant in the region, has been effective in Corbett National Park, Uttarakhand, India where they used root stock cuttings and manual removal of the species (Love et al., 2009). Restoration work with native grass was done immediately to prevent re-invasion or secondary invasion by other exotic species. The results were successful (Babu et al., 2009). Before attempting eradication, detailed research on the ecological role of dominating intruders is required.

\section{RESULTS AND DISCUSSION}

About 190alien species belonging to 51 flowering plant groups were discovered in India's lower Shivalik range during the study conducted in Himachal Pradesh in 2002-2004 (Singh et al., 2014). In Kashmir, a total of 43 invasive alien plant species of 41 genera were found in the area, representing 25 families. Amaranthaceae, Asteraceae, Brassicaceae, Euphorbiaceae and Poaceae were among the notable families that contributed to the foreign crowd (Shaheen et al., 2019). Punjab with less forest cover has most invasive plants belonging to the
Asteraceae family followed by Poaceae, Solanaceae, and Fabaceae. Among the FIS in Uttarakhand, Asteraceae family dominates with 18 species in 16 genera, followed by Fabaceae (8 species, 6 genera), Amaranthaceae ( 7 species, 4 genera), Convovlvulaceae (7 species, 3 genera), Malvaceae (7 species, 6 genera), Solanaceae (6 species, 4 genera), Poaceae (4 species, 3 genera), Euphorbiaceae (4 species, 2 genera) constituting the eight dominant families of FIS (Rastogi et al., 2015).

Lantana camara, Parthenium hysterophorus, and Ageratum conyzoides are among the alien invasive species in the IHR that are significantly harming plant variety and biological integrity of Himalayan ecosystems due to their widespread distribution which includes the Shivaliks (Dobhal et al., 2011). Prevention, eradication and restoration at an early stage can prevent this FIS from dominating the real ecosystem. Table 1 shows the hhighly propagative FIS in some States of Shivaliks.

\section{CONCLUSION}

This study brings us to a few conclusions. Despite the fact that Shivaliks has a distinct biodiversity, the region is threatened when it comes to FIS. Ageratum conyzoides, Lantana camara and Parthenium hysterophorus are widely dispersed and quickly reproducing. In order to manage FIS in the region, it is essential to link such species to alternative livelihood opportunities, keeping a caution that such ventures may not turn into commercial business leading to unplanned and non-scientific extraction for constant supply of raw materials. Instead feasibility study and experimentation are required to utilize these in forest nursery and plantation works as green manure, biodegradable containers and potting mixture etc.This study is merely a review to show that the FIS of Shivaliks is important as it is a part of IHR, a rich biodiversity for India. In future a researched study with a good framework may help in developing a database to document knowledge gaps and plan management strategies.

\section{ACKNOWLEDGEMENT}

Director of the Institute is thanked for providing facilities. The financial assistance to the author Priya P from Department of Science and Technology, India (SR/WOS-A/LS-198/2017) is gratefully acknowledged. 


\section{REFERENCES}

1. Alexander, J. M., Kueffer, C., Daehler, C. C., Edwards, P. J., Pauchard, A., Seipel, T., \& Miren Consortium. (2011). Assembly of nonnative floras along elevational gradients explained by directional ecological filtering. Proceedings of the National Academy of Sciences, 108(2), 656-661.

2. Babu, S., Love, A., \& Babu, C. R. (2009). Ecological restoration of lantana-invaded landscapes in Corbett Tiger Reserve, India. Ecological Restoration, 27(4), 467-477.

3. Caut, S., Angulo, E., \& Courchamp, F. (2009). Avoiding surprise effects on Surprise Island: alien species control in a multitrophic level perspective. Biological Invasions, 11(7), 1689-1703.

4. Day, M. D., Wiley, C. J., Playford, J., \& Zalucki, M. P. (2003). Lantana: current management status and future prospects (No. 435-201633733).

5. De Terra, H. (1933). Himalayan and Alpine orogenesis. Intern. Geol. Congr., 16th, Washington, 1933, Rept., 2: 859-872.

6. Dietz, H., \& Edwards, P. J. (2006). Recognition that causal processes change during plant invasion helps explain conflicts in evidence. Ecology, 87(6), 1359-1367.

7. Dobhal, P. K., Kohli, R. K., \& Batish, D. R. (2011). Impact of Lantana camara L. invasion on riparian vegetation of Nayar region in Garhwal Himalayas (Uttarakhand, India). Journal of Ecology and the Natural Environment, 3(1), 1122.

8. Ehrenfeld, J. G. (2003). Effects of exotic plant invasions on soil nutrient cycling processes. Ecosystems, 6(6), 503-523.

9. Hiremath, A. J., \& Sundaram, B. (2005). The fire-lantana cycle hypothesis in Indian forests. Conservation and Society, 26-42.

10. Hooker, J. D. (1890). The Flora of British India (Vol. 5). L. Reeve.

11. Huddle, J. A., Awada, T., Martin, D. L., Zhou, X., Pegg, S. E., \& Josiah, S. J. (2011). Do invasive riparian woody plants affect hydrology and ecosystem processes?. Great Plains Research, 49-71.
12. Hulme, P. E. (2003). Biological invasions: winning the science battles but losing the conservation war?. Oryx, 37(2), 178-193.

13. Hulme, P. E. (2009). Trade, transport and trouble: managing invasive species pathways in an era of globalization. Journal of applied ecology, 46(1), 10-18.

14. Sekar, K. C. (2012). Invasive alien plants of Indian Himalayan region-diversity and implication. American Journal of Plant Sciences, 2012.

15. Khuroo, A. A., Rashid, I., Reshi, Z., Dar, G. H., \& Wafai, B. A. (2007). The alien flora of Kashmir Himalaya. Biological Invasions, 9(3), 269-292.

16. Khuroo,A.A., Reshi, Z.A., Malik,A.H., Weber, E., Rashid, I., \& Dar, G. H. (2012). Alien flora of India: taxonomic composition, invasion status and biogeographic affiliations. Biological Invasions, 14(1), 99-113.

17. Kirschbaum, M. U. (2000). Forest growth and species distribution in a changing climate. Tree physiology, 20(5-6), 309-322.

18. Kohli, R. K., \& Daizy, R. (1994). Parthenium hysterophorus - a review. Research Bulletin of the Panjab University, Science, 44(1/4), 105-149.

19. Kohli, R. K., Batish, D. R., Singh, H. P., \& Dogra, K. S. (2006). Status, invasiveness and environmental threats of three tropical American invasive weeds (Parthenium hysterophorus L., Ageratum conyzoides L., Lantana camara L.) in India. Biological Invasions, 8(7), 1501-1510.

20. Kohli, R. K., Dogra, K. S., Batish, D. R., \& Singh, H. P. (2004). Impact of Invasive Plants on the Structure and Composition of Natural Vegetation of North western Indian Himalayas1. Weed Technology, 18(sp1), 1296-1300.

21. Kosaka, Y., Saikia, B., Mingki, T., Tag, H., Riba, T., \& Ando, K. (2010). Roadside distribution patterns of invasive alien plants along an altitudinal gradient in Arunachal Himalaya, India. Mountain Research and Development, 30(3), 252258.

22. Love, A., Babu, S., \& Babu, C. R. (2009). Management of Lantana, an invasive alien weed, in forest ecosystems of India. Current Science, 1421-1429. 
23. McDougall, K. L., Alexander, J. M., Haider, S., Pauchard, A., Walsh, N. G., \& Kueffer, C. (2011). Alien flora of mountains: global comparisons for the development of local preventive measures against plant invasions. Diversity and Distributions, 17(1), 103-111.

24. McGeoch, M. A., Butchart, S. H., Spear, D., Marais, E., Kleynhans, E. J., Symes, A., ... \& Hoffmann, M. (2010). Global indicators of biological invasion: species numbers, biodiversity impact and policy responses. Diversity and Distributions, 16(1), 95-108.

25. Millennium Ecosystem Assessment, 2005.

26. Murali, K. S., \& Setty, R. S. (2001). Effect of weeds Lantana camara and Chromelinaodorata growth on the species diversity, regeneration and stem density of tree and shrub layer in BRT sanctuary. Current Science, 675-678.

27. Myers, N. (1993). Environmental refugees in a globally warmed world. Bioscience, 43(11), 752761.

28. Nagar, P. S., Pathak, S. J., \& Pandya, S. M. (2004). The alien flora of the Barda hills and its surroundings in Gujarat, India. Indian Journal of Forestry, 7(1), 25-38.

29. Negi, V. S., Joshi, B. C., Pathak, R., Rawal, R. S., \& Sekar, K. C. (2018). Assessment of fuelwood diversity and consumption patterns in cold desert part of Indian Himalaya: implication for conservation and quality of life. Journal of Cleaner Production, 196, 23-31.

30. Palni, L. M. S., \& Rawal, R. S. (2013). The Himalayan biodiversity: richness, representativeness, uniqueness and life-support values. GB Pant Institute of Himalayan Environment and Development (GBPIHED), Almora, 84.

31. Pandey, R. P., \& Parmar, P. J. (1994). The exotic flora of Rajasthan. Journal of Economic and Taxonomic Botany, 18(1), 105-121.

32. Pathak, R., Negi, V. S., Rawal, R. S., \& Bhatt, I. D. (2019). Alien plant invasion in the Indian Himalayan Region: state of knowledge and research priorities. Biodiversity and Conservation, 28(12), 3073-3102.

33. Pauchard, A., Kueffer, C., Dietz, H., Daehler, C. C., Alexander, J., Edwards, P. J., ... \& Seipel, T.
(2009). Ain't no mountain high enough: plant invasions reaching new elevations. Frontiers in Ecology and the Environment, 7(9), 479-486.

34. Priya, P \& Chittibabu CV (2018). A Comparative study on the ethnomedicines of the Shivalik patches along the five states of northern India. International Journal on Biological Sciences,8(2), 1421-1429.

35. Rastogi, J., Rawat, D. S., \& Chandra, S. (2015). Diversity of invasive alien species in Pantnagar flora. Tropical Plant Research, 2(3), 282-287.

36. Schweiger, O., Biesmeijer, J. C., Bommarco, R., Hickler, T., Hulme, P. E., Klotz, S., ... \& Settele, J. (2010). Multiple stressors on biotic interactions: how climate change and alien species interact to affect pollination. Biological Reviews, 85(4), 777-795.

37. Shaheen, H., Batool, A., Gillani, S. F., Dar, M. E. I., Habib, T., \& Aziz, S. (2019). Diversity and distribution of invasive plant species in suburban vegetation of Kashmir Himalayas. Pol. J. Environ. Stud, 28(4), 2823-2833.

38. Sharma, E., Molden, D., Wester, P., \& Shrestha, R. M. (2016). The Hindu Kush Himalayan monitoring and assessment programme: action to sustain a global asset. Mountain Research and Development, 36(2), 236-239.

39. Sharma, G. P., \& Raghubanshi, A. S. (2010). How Lantana invades dry deciduous forest: a case study from Vindhyan highlands, India. Tropical Ecology, 51(2), 305-316.

40. Singh, H. P., Batish, D. R., Dogra, K. S., Kaur, S., Kohli, R. K., \& Negi, A. (2014). Negative effect of litter of invasive weed Lantana camara on structure and composition of vegetation in the lower Siwalik Hills, northern India. Environmental monitoring and assessment, 186(6), 3379-3389.

41. Singh, K. P., Shukla, A. N., \& Singh, J. S. (2010). State-level inventory of invasive alien plants, their source regions and use potential. Current Science, 107-114.

42. Tilman, D. (1999). The ecological consequences of changes in biodiversity: a search for general principles. Ecology, 80(5), 1455-1474.

43. Vilà, M., Weber, E., \& Antonio, C. M. (2000). Conservation implications of invasion by plant 
hybridization. Biological invasions, 2(3), 207217.

44. Vitousek, P. M., D'Antonio, C. M., Loope, L. L., \& Westbrooks, R. (1996). Biological invasions as global environmental change.

45. Wilcove, D. S., Rothstein, D., Dubow, J., Phillips, A., \& Losos, E. (1998). Quantifying threats to imperiled species in the United States. BioScience, 48(8), 607-615.
46. Williamson, M. (1999). Invasions. Ecography, 22(1), 5-12.

47. Williamson, M., \& Fitter, A. (1996). The varying success of invaders. Ecology, 77(6), 1661-1666.

48. Yurkonis, K. A., Meiners, S. J., \&Wachholder, B. E. (2005). Invasion impacts diversity through altered community dynamics. Journal of ecology, 93(6), 1053-1061. 